\title{
Manganese Oxidation State Assignment for Manganese Catalase
}

DOI:

10.1021/jacs.6b02600

\section{Document Version}

Accepted author manuscript

Link to publication record in Manchester Research Explorer

\section{Citation for published version (APA):}

Beal, N., \& O'Malley, P. (2016). Manganese Oxidation State Assignment for Manganese Catalase. Journal of the American Chemical Society, 138(13), 4358-4361. https://doi.org/10.1021/jacs.6b02600

\section{Published in:}

Journal of the American Chemical Society

\section{Citing this paper}

Please note that where the full-text provided on Manchester Research Explorer is the Author Accepted Manuscript or Proof version this may differ from the final Published version. If citing, it is advised that you check and use the publisher's definitive version.

\section{General rights}

Copyright and moral rights for the publications made accessible in the Research Explorer are retained by the authors and/or other copyright owners and it is a condition of accessing publications that users recognise and abide by the legal requirements associated with these rights.

\section{Takedown policy}

If you believe that this document breaches copyright please refer to the University of Manchester's Takedown Procedures [http://man.ac.uk/04Y6Bo] or contact uml.scholarlycommunications@manchester.ac.uk providing relevant details, so we can investigate your claim.

\section{OPEN ACCESS}




\title{
Manganese Oxidation State Assignment for Manganese Catalase
}

\author{
Nathan J. Beal and Patrick J. O'Malley* \\ School of Chemistry, The University of Manchester, Oxford Road, Manchester, M13 9PL, United Kingdom
}

\section{Supporting Information}

ABSTRACT: The oxidation state assignment of the manganese ions present in the superoxidized manganese (III/IV) catalase active site is determined by comparing experimental and broken symmetry density functional theory calculated ${ }^{14} \mathrm{~N},{ }^{17} \mathrm{O}$, and ${ }^{1} \mathrm{H}$ hyperfine couplings. Experimental results have been interpreted to indicate that the substrate water is coordinated to the $\mathrm{Mn}$ (III) ion. However, by calculating hyperfine couplings for both scenarios we show that water is coordinated to the $\mathrm{Mn}(\mathrm{IV})$ ion and that the assigned oxidation states of the two manganese ions present in the site are the opposite of that previously proposed based on experimental measurements alone.

$\mathrm{T}$ he mechanism of water oxidation catalyzed by the oxygenevolving complex (OEC) of photosystem II (PSII) remains one of nature's great mysteries. Due in large part to the availability of accurate structural information obtained from recent high-resolution crystal structures, ${ }^{1,2}$ the mechanism of water oxidation is gradually yielding its secrets. In addition to its fundamental biological importance, this knowledge is vital for developing future artificial photosynthetic devices capable of hydrogen production from water. ${ }^{3-5}$ During the catalytic cycle, the OEC, comprising at its core a $\mathrm{Mn}_{4} \mathrm{CaO}_{5}$ complex, cycles through five distinct oxidation states known as the $\mathrm{S}_{n}$ states (where $n=0-4){ }^{6}$ To fully understand water oxidation, it is necessary to obtain an understanding of the key intermediates and stages involved at both a structural and electronic level. This is a crucial step in the elucidation of plausible water oxidation mechanisms. Electron paramagnetic resonance (EPR) studies and high-resolution variants thereof have been at the forefront in revealing electronic level information about the intermediate states. ${ }^{7}$ Even with high-resolution EPR methods, however, the assignment of hyperfine couplings (hfcs) to nuclear positions is often difficult and speculative. The utility of DFT calculations in assigning EPR hfcs for organic free radicals has been appreciated for some time. ${ }^{8}$ More recent reports have demonstrated that for exchange coupled metal clusters such as the OEC, combined EPR and broken symmetry density functional theory (BS-DFT) calculations can be equally effective. $^{9}$

Manganese catalase, a dimanganese complex which catalyzes the disproportionation of hydrogen peroxide to water and molecular oxygen, has been proposed to be an evolutionary precursor of the OEC. ${ }^{10,11}$ Additionally the active site of superoxidized manganese (III/IV) catalase, seen in Figure 1, has been used as a proteinaceous model of the $S_{2}$ state of the OEC. In contrast to the synthetic dimanganese complexes also

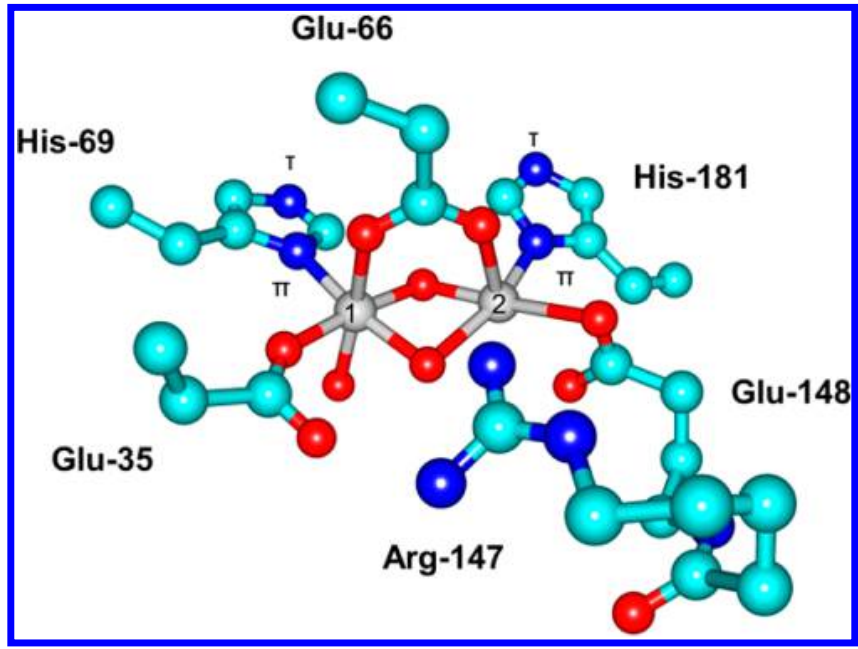

Figure 1. Model of the manganese catalase active site used in this study; each $\mathrm{Mn}$ ion is coordinated by one histidine and one glutamate residue with the two $\mathrm{Mn}$ ions bridged by a single glutamate residue and two $\mu$-oxo bridges.

used to model the OEC, superoxidized manganese catalase is able to mimic important features of the protein environment surrounding the OEC such as the coordination by protein side chains and a water molecule. ${ }^{12,13}$ The di $\mu$-oxo glutamate motif together with further glutamate and histidine ligation closely resembles the manganese ligation in the OEC. Although catalytically inactive, ${ }^{14,15}$ the superoxidized $\mathrm{Mn}(\mathrm{III}) / \mathrm{Mn}(\mathrm{IV})$ state displays an effective $S=1 / 2$ ground spin state and has an EPR spectrum similar to that of the $S=1 / 2, S_{0}$ and $S_{2}$ states of the OEC. ${ }^{16,17}$

Many EPR studies have exploited this simpler manganese catalase active site as a model for the $S_{2}$ state of the OEC. ${ }^{12,18}$ In particular recent measurements of ligand ${ }^{17} \mathrm{O},{ }^{14} \mathrm{~N}$ and ${ }^{1} \mathrm{H}$ hfcs have been performed, and the assignments in manganese catalase and synthetic dimanganese model complexes have been used as guides for the assignment of similar hfcs observed in the $\mathrm{OEC}_{2}$ state. ${ }^{19-21}$ As mentioned previously assignment of hfcs to particular atom positions is aided considerably by BS-DFT calculations on large active site models. While some earlier BSDFT studies using the catalase active site have been performed, in particular discounting the possibility of protonated oxo bridges in the superoxidized state, ${ }^{22,23}$ there has been no analysis of the more recently obtained ENDOR and HYSCORE data.

Received: March 10, 2016 
A key fundamental question in the manganese catalase superoxidized III/IV state is the assignment of the correct oxidation state to each Mn. Recent experimental EPR studies have been interpreted to indicate that $\mathrm{Mn}_{1}$ is in the III oxidation state with $\mathrm{Mn}_{2}$ having the IV oxidation state. ${ }^{12,13}$ This assignment was based mainly on comparison of measured hfcs with values found for model complexes. ${ }^{12,20}$ In this study we use BS-DFT calculations to calculate hfc and quadrupole couplings for the nuclei in models of the superoxidized manganese catalase site. We focus on models of the catalytic site where $\mathrm{Mn}_{1}$ and $\mathrm{Mn}_{2}$ are either in the III or IV oxidation state and use the comparison of calculated and experimental hyperfine and quadrupole couplings to decipher the correct oxidation state assignment. Models A and B differ in the assignment of the oxidation states to the structurally inequivalent manganese sites. Model $\mathrm{A}$ has $\mathrm{Mn}_{1}$ in the IV oxidation state and $\mathrm{Mn}_{2}$ in the III oxidation state with model B being the opposite. Model $\mathrm{A}(\mathrm{OH})$ has the same oxidation state assignment as model $\mathrm{A}$ but has a hydroxide bonded to $\mathrm{Mn}_{1}$ instead of a water. Azide inhibited manganese catalase has also been studied using models $\mathrm{C}$ and $\mathrm{D}$ where the azide anion replaces the water bound to $\mathrm{Mn}_{1}$. Model $\mathrm{C}$ has the same oxidation state assignment as model $\mathrm{A}$ and model $\mathrm{D}$ the same as model B. The numbering scheme used throughout this study is shown in Figure 2. At present there is no X-ray structure

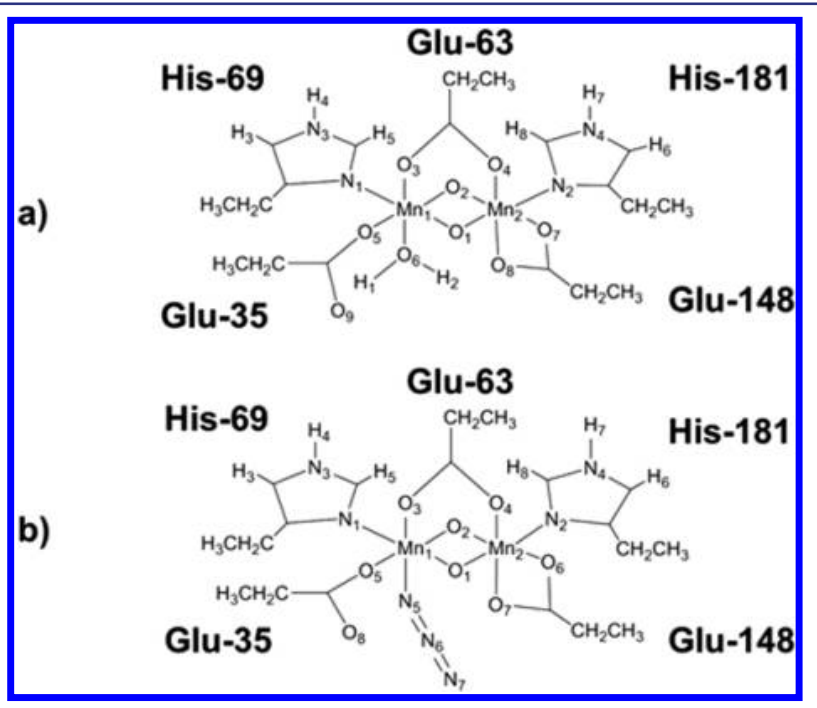

Figure 2. Numbering scheme used throughout this work for the manganese catalase models: (a) shows the numbering scheme for $\mathrm{A}$, $\mathrm{A}(\mathrm{OH})$, and $\mathrm{B}$, while $(\mathrm{b})$ is the numbering scheme used for the azide models $\mathrm{C}$ and D. For clarity the Arg-147 residue has been omitted.

available for the III/IV superoxidized state of manganese catalase. As a result of this, the study used the X-ray structure of manganese catalase derived from Lactobacillus plantarum in the $\mathrm{Mn}^{\mathrm{III}} / \mathrm{Mn}^{\mathrm{III}}$ state as a starting structure. ${ }^{24}$

Models A, A(OH), and B have calculated bond lengths, Heisenberg exchange coupling constants, and ${ }^{55} \mathrm{Mn}$ hyperfine hfcs which are all in good agreement with the experimental data and previous DFT calculations on smaller model systems, and these are presented in the Supporting Information (SI). Based on these data alone, no model can be found which gives superior agreement with the experimental data. A better distinction between the models arises when comparing experimental and calculated ${ }^{14} \mathrm{~N},{ }^{17} \mathrm{O}$ hfcs and nuclear quadrupole coupling data. Spin projected ${ }^{14} \mathrm{~N}$ hfcs and quadrupolar parameters are given in Table 1 for models $\mathrm{A}$, $\mathrm{A}(\mathrm{OH})$, and $\mathrm{B}$ and in Table 2 for models $\mathrm{C}$ and $\mathrm{D}$.

Table 1. Spin Projected ${ }^{14} \mathrm{~N}$ Isotropic Hyperfine Couplings $(\mathrm{MHz})$ and $\mathrm{K}^{2}\left(3+\eta^{2}\right)\left(\mathrm{MHz}^{2}\right)$ for Models $\mathrm{A}, \mathrm{A}(\mathrm{OH})$, and $\mathrm{B}$

\begin{tabular}{clrrr} 
nucleus & parameter & \multicolumn{1}{c}{$\mathrm{A}$} & $\mathrm{A}(\mathrm{OH})$ & \multicolumn{1}{c}{$\mathrm{B}$} \\
$\pi$ - $\mathrm{N}_{1}($ His-69) & $A_{\text {iso }}$ & +3.0 & +2.7 & -4.3 \\
& $K^{2}\left(3+\eta^{2}\right)$ & 0.7 & 0.9 & 0.8 \\
$\pi$ - $\mathrm{N}_{2}($ His-181) & $A_{\text {iso }}$ & -4.6 & -4.1 & +2.7 \\
& $K^{2}\left(3+\eta^{2}\right)$ & 0.9 & 1.0 & 0.8 \\
\hline
\end{tabular}

Table 2. Spin Projected ${ }^{14} \mathrm{~N}$ Isotropic Hyperfine Couplings $(\mathrm{MHz})$ and $\mathrm{K}^{2}\left(3+\eta^{2}\right)\left(\mathrm{MHz}^{2}\right)$ for the Azide Inhibited Models C and D

\begin{tabular}{llrcc}
\multicolumn{1}{c}{ nucleus } & parameter & \multicolumn{1}{c}{$\mathrm{C}$} & $\mathrm{D}$ & $\mathrm{exptl}^{12}$ \\
$\pi$ - $\mathrm{N}_{1}($ His-69) & $A_{\text {iso }}$ & +2.9 & -0.21 & $|3.5|( \pm 0.2)$ \\
& $K^{2}\left(3+\eta^{2}\right)$ & 0.9 & 1.0 & $1( \pm 0.02)$ \\
$\pi-\mathrm{N}_{2}($ His-181 $)$ & $A_{\text {iso }}$ & -4.2 & +2.0 & $|6.4|( \pm 0.5)$ \\
& $K^{2}\left(3+\eta^{2}\right)$ & 1.0 & 1.0 & $0.9( \pm 0.02)$ \\
$\mathrm{N}_{5}($ azide $)$ & $A_{\text {iso }}$ & +1.2 & +14.7 & $|2.5|( \pm 0.5)$ \\
& $K^{2}\left(3+\eta^{2}\right)$ & 1.7 & 1.3 & $1.6( \pm 0.02)$ \\
$\mathrm{N}_{6}($ azide $)$ & $A_{\text {iso }}$ & -0.6 & +1.2 & - \\
& $K^{2}\left(3+\eta^{2}\right)$ & 0.1 & 0.1 & - \\
$\mathrm{N}_{7}($ azide $)$ & $A_{\text {iso }}$ & -0.1 & +1.4 & - \\
& $K^{2}\left(3+\eta^{2}\right)$ & 0.5 & 0.3 & - \\
\hline
\end{tabular}

Our A, A(OH), and B models give calculated isotropic hfc values of 3.0, 2.7, and $2.7 \mathrm{MHz}$, respectively, for the histidine $\pi$ nitrogen bound to the $\mathrm{Mn}(\mathrm{IV})$ and $-4.6,-4.1$, and $-4.3 \mathrm{MHz}$ for the $\pi$-nitrogen bound to the $\mathrm{Mn}(\mathrm{III})$. These are in general agreement with the experimentally observed values of -5.75 and $-6.0 \mathrm{MHz}$ experimentally assigned to a $\mathrm{Mn}$ (III) ligand nitrogen and 2.7 and $3.0 \mathrm{MHz}$ assigned to a $\mathrm{Mn}(\mathrm{IV}) .{ }^{12,18}$ Model B is in direct agreement with the experimental assignments which assigned $\mathrm{Mn} 1$ as $\mathrm{Mn}$ (III), however model $A$ and model $\mathrm{A}(\mathrm{OH})$ show equally good agreement and thus do not allow a distinction to be made between the different models.

Comparison of the calculated ${ }^{14} \mathrm{~N}$ hfcs for the azide models $\mathrm{C}$ and $\mathrm{D}$, Table 2, does enable us to make a clear distinction between the oxidation state assignments of $\mathrm{Mn}_{1}$ and $\mathrm{Mn}_{2}$. Here, by comparing the calculated hfc data for the azide inhibited models, it is shown that model $\mathrm{C}$, i.e., where $\mathrm{Mn}_{1}$ is in the IV oxidation state, gives unique agreement with the experimental hfc for the azide nitrogen. Table 2 shows that binding of the azide ion to $\mathrm{Mn}_{1}$ (III), seen in model $\mathrm{D}$, results in a calculated isotropic hfc of $14.7 \mathrm{MHz}$ for the azide $\mathrm{N}_{5}$ atom which far exceeds the experimentally observed value of $2.5 \mathrm{MHz}$. The large magnitude of the calculated hfc can be attributed to the Jahn-Teller axis lying along the $\mathrm{Mn}(\mathrm{III})-\mathrm{N}$ azide bond. This results in a significant transfer of spin density from $\mathrm{Mn}$ (III) to the nitrogen nucleus, via the occupied $\mathrm{Mn}(\mathrm{III}) \mathrm{d}_{z^{2}}$ orbital, leading to a correspondingly large magnitude ${ }^{14} \mathrm{~N}$ isotropic hfc. For model C, by contrast, where the $\mathrm{Mn}_{1}$ is in the IV oxidation state, the calculated hfc value of $1.2 \mathrm{MHz}$ for the azide nitrogen is much closer in magnitude to the experimental value of 2.5 $\mathrm{MHz}$. These calculated hfcs, therefore, provide a clear distinction between the different oxidation state models $\mathrm{C}$ and $\mathrm{D}$ and strongly indicate that $\mathrm{Mn}_{1}$ is $\mathrm{Mn}(\mathrm{IV})$ and $\mathrm{Mn}_{2}$ is $\mathrm{Mn}(\mathrm{III})$, in disagreement with the assignments made previously. 
It is possible that the large magnitude hfc value for the azide $\mathrm{N}$ of $14.7 \mathrm{MHz}$, calculated for model $\mathrm{D}$, precludes efficient nuclear state mixing needed for HYSCORE and may not be detectable. $^{18}$ The observed experimental value might then correspond to the smaller isotropic hfcs of the azide $\mathrm{N}_{6}$ or $\mathrm{N}_{7}$ atoms of Figure 2. However, the calculated quadrupolar values, $K^{2}\left(3+\eta^{2}\right)$, for both of these nitrogens, Table 2 , are significantly different from that observed experimentally and would not support this assignment. A further reason to reject the model D oxidation state assignment is the relatively poor agreement between the calculated and experimental hfcs for the histidine $\pi$-nitrogens, $\mathrm{N}_{1}$ and $\mathrm{N}_{2}$ for this model. The calculated hfcs, Table 2, are significantly lower than the experimental values. This may arise from the negative azide anion coordinating to $\mathrm{Mn}_{1}$ (III) along the Jahn-Teller axis. This leads to a lengthening of the $\mathrm{Mn}-\pi-\mathrm{N}$ bonds which were found to be an average of $0.08 \AA$ longer in model $\mathrm{D}$ than they were in model B. Full tables of the bond lengths for all models can be found in the SI.

In all of the models, the Mn(III) Jahn-Teller axis was found to lie perpendicular to the $\mu$-oxo bridges, a finding that is echoed in earlier studies of manganese catalase and many synthetic mixed valence $\mathrm{Mn}$ (III)/Mn(IV) dimer complexes. ${ }^{9,25}$ This disagrees with the interpretation of Coates et al. where the azide nitrogen was assigned as a ligand to $\mathrm{Mn}(\mathrm{III})$ in an equatorial position. ${ }^{12}$ It is possible that the azide ligand could cause a switch of oxidation states on replacement of the water molecule on $\mathrm{Mn}_{1}$. However, further support for the above assignment of oxidation states in the uninhibited system comes from ${ }^{17} \mathrm{O}$ hfc data measured for the water molecule ligated to $\mathrm{Mn}_{1}$. An experimental ${ }^{17} \mathrm{O}$ isotropic hfc of magnitude 1.5 or 3.8 $\mathrm{MHz}$ was recently measured for the water oxygen. ${ }^{13,26}$ Spin projected ${ }^{17} \mathrm{O}$ isotropic hfcs for models $\mathrm{A}, \mathrm{A}(\mathrm{OH})$, and $\mathrm{B}$ are shown in Table 3. A comparison of the calculated results for the

Table 3. Calculated Spin Projected ${ }^{17} \mathrm{O}$ Isotropic Hyperfine Couplings $(\mathrm{MHz})$ for the Models $\mathrm{A}, \mathrm{A}(\mathrm{OH})$, and B

\begin{tabular}{cccccc}
\multicolumn{1}{c}{ nucleus } & parameter & A & $(\mathrm{OH})$ & B & exptl $^{13,26}$ \\
water/hydroxide $\mathrm{O}_{6}$ & $A_{\text {iso }}$ & +2.4 & +4.5 & -18.1 & $|1.5|$ or $|3.8|$ \\
\hline
\end{tabular}

three model systems with the experimental value strongly supports either model A or model $\mathrm{A}(\mathrm{OH})$. Table 3 shows that the model $\mathrm{B}$ calculated ${ }^{17} \mathrm{O}$ isotropic hfc, $-18.1 \mathrm{MHz}$, is significantly larger in magnitude than the experimental value. This is due to the water oxygen ligating along the $\mathrm{Mn}$ (III) Jahn-Teller axis and similar to the azide nitrogen, a large magnitude isotropic hfc arises due to direct transfer of spin density from the $\mathrm{Mn}(\mathrm{III}) \mathrm{d}_{z^{2}}$ orbital. The isotropic hfc values calculated for models $\mathrm{A}$ and $\mathrm{A}(\mathrm{OH})$, where the oxygen is ligated to a $\mathrm{Mn}(\mathrm{IV})$ ion, and an empty $\mathrm{d}_{z^{2}}$ orbital is much smaller in magnitude and exhibits much closer agreement with the small experimental hfc of magnitude 1.5 or $3.8 \mathrm{MHz}$.

Crystal structure and molecular dynamics simulations of the III/III form show clear 6-coordination at the $\mathrm{Mn}_{1}$ site, whereas the $\mathrm{Mn}_{2}$ site is best described as 5-coordinate square pyramidal (see SI). ${ }^{24,27,28}$ In the IV/III superoxidized form, therefore, the preference of $\mathrm{Mn}$ (IV) for 6-coordination at $\mathrm{Mn}_{1}$ found above is rationalized by the higher coordination number with the more extreme Jahn-Teller $\mathrm{Mn}_{2}$ site favoring $\mathrm{Mn}$ (III).

${ }^{1} \mathrm{H}$ hfc data have been obtained using 2D HYSCORE spectroscopy by Coates et al., ${ }^{12}$ who observed two signals HA and HB. Due to its disappearance in deuterated water, the HA signal was experimentally assigned to the proton(s) of the water molecule coordinated to $\mathrm{Mn}_{1}$ and was measured with $A_{\text {iso }}=$ I 3.3 $\mathrm{MHz}$ and $T=16.71 \mathrm{MHz}$, which was interpreted to indicate that $\mathrm{Mn}_{1}$ was in the III oxidation state. Modeling of the proton hfcs is complicated due to the absence of proton coordinates from the crystal structure determination. The water protons can occupy a large conformational space, and to account for this uncertainty, the proton hfc was calculated over a range of possible conformations by varying the dihedral angle the protons make with the $\mathrm{Mn} \mu$-oxo bonds as described in the SI. Table 4 shows the range of values calculated for the isotropic and anisotropic hfcs for the water protons ligated to $\mathrm{Mn}_{1}$ for each of the three models.

Table 4. Selected Spin Projected ${ }^{1} \mathbf{H}$ Isotropic and Anisotropic Hyperfine Couplings ( $\mathrm{MHz}$ ) for the Models A, $\mathrm{A}(\mathrm{OH})$, and $\mathrm{B}$

\begin{tabular}{|c|c|c|c|c|}
\hline nucleus & parameter & A & $\mathrm{A}(\mathrm{OH})$ & B \\
\hline \multirow[t]{2}{*}{$\begin{array}{l}\text { water/hydroxide } \\
\mathrm{H}_{1}\end{array}$} & $A_{\text {iso }}$ & -0.7 to -5.3 & $\begin{array}{r}-6.8 \text { to } \\
-10.0\end{array}$ & 0.1 to -1.3 \\
\hline & $T$ & -4.3 to -5.1 & -5.2 to -6.3 & +8.3 to +9.6 \\
\hline \multirow{2}{*}{$\begin{array}{l}\text { water/hydroxide } \\
\mathrm{H}_{2}\end{array}$} & $A_{\text {iso }}$ & -0.6 to -3.8 & - & 0.0 to -1.1 \\
\hline & $T$ & -4.2 to -4.7 & - & +7.5 to +8.6 \\
\hline \multirow[t]{2}{*}{ His $69 \mathrm{H}_{5}$} & $A_{\text {iso }}$ & +0.4 & +0.4 & -0.6 \\
\hline & $T$ & -2.3 & -2.4 & +4.5 \\
\hline \multirow[t]{2}{*}{ His $181 \mathrm{H}_{8}$} & $A_{\text {iso }}$ & -0.7 & -0.5 & +0.4 \\
\hline & $T$ & +5.0 & +5.2 & -2.6 \\
\hline
\end{tabular}

For model B, the calculated isotropic hfc values for the water protons range between 0.1 to $-1.3 \mathrm{MHz}$ as the water group is rotated. This is significantly less than the experimental value of I 3.3 $\mathrm{MHz}$. The anisotropic hfcs were found to vary between 7.5 and $9.6 \mathrm{MHz}$, slightly higher than the experimental anisotropic hfc value of $16.7 \mid \mathrm{MHz}$. The calculated isotropic hfc for the hydroxide proton in model $\mathrm{A}(\mathrm{OH})$ was found to range from -6.8 to $-10.0 \mathrm{MHz}$, higher in magnitude than the experimental isotropic hfc, while the anisotropic hfc for the hydroxide proton ranged in value from -5.3 to $-6.3 \mathrm{MHz}$ in better agreement with the experimental anisotropic hfc of $6.7 \mathrm{MHz}$. The isotropic $\mathrm{hfc}$ values for the water protons in model A were found to vary the most out of the three models considered. The isotropic hfc values for the water protons were calculated to range between -0.6 and $-5.3 \mathrm{MHz}$, while the anisotropic hfc value ranges between -4.2 to $-5.1 \mathrm{MHz}$.

Unfortunately it is not possible based on the proton data calculated to definitively favor any model. The uncertainty in the location of the water protons makes it difficult to arrive at any firm conclusions. In the experimental studies it was argued that the magnitude of the hfcs observed for the water proton ruled out water coordination to a $\mathrm{Mn}(\mathrm{IV})$ ion. ${ }^{12,13}$ Our calculated hfcs show that this is not the case and that water coordination to $\mathrm{Mn}$ (IV) is as likely as coordination to $\mathrm{Mn}$ (III) based on the experimentally measured values.

The second proton coupling, HB measured with $A_{\text {iso }}=|1.0|$ $\mathrm{MHz}$ and $T=|5.5| \mathrm{MHz}$, was experimentally assigned to the proximal proton of the histidine residue ligated to $\mathrm{Mn}$ (III). This would correspond to $\mathrm{H}_{5}$ or $\mathrm{H}_{8}$ in our models shown in Figure 2. Table 4 shows that couplings close to these values are indeed calculated for the proximal proton of the histidine residue bound to the $\mathrm{Mn}(\mathrm{III})$ ion, i.e., His-181 in the A models and His-69 in model B. Based on our current assignment of the 
$\mathrm{Mn}$ (III) oxidation state to $\mathrm{Mn}_{2}$, we attribute this proton coupling as arising from the proximal proton on the His-181 residue and not the His-69 residue as assigned by Coates et al. ${ }^{12}$

In summary, comparison of BS-DFT calculated hfcs of the superoxidized state of manganese catalase with experimental results shows that the $\mathrm{Mn}_{1}$ center is in the IV oxidation state with the $\mathrm{Mn}_{2}$ center having the III oxidation state. These results are completely opposite to the interpretation suggested based solely on experimental results. The water molecule bound to $\mathrm{Mn}_{1}$ (IV) most likely remains fully protonated and does not become a hydroxide in the superoxidized state of manganese catalase.

\section{ASSOCIATED CONTENT}

\section{S Supporting Information}

The Supporting Information is available free of charge on the ACS Publications website at DOI: 10.1021/jacs.6b02600.

Computational details and data (PDF)

\section{AUTHOR INFORMATION}

\section{Corresponding Author}

*Patrick.omalley@manchester.ac.uk

\section{Notes}

The authors declare no competing financial interest.

\section{ACKNOWLEDGMENTS}

N.J.B. gratefully acknowledges the award of a BBSRC DTP studentship. The authors would like to acknowledge the use of the computational shared facility (CSF) at The University of Manchester.

\section{REFERENCES}

(1) Umena, Y.; Kawakami, K.; Shen, J. R.; Kamiya, N. Nature 2011, 473 (7345), 55.

(2) Suga, M.; Akita, F.; Hirata, K.; Ueno, G.; Murakami, H.; Nakajima, Y.; Shimizu, T.; Yamashita, K.; Yamamoto, M.; Ago, H.; Shen, J.-R. Nature 2014, 517 (7532), 99.

(3) Cook, T. R.; Dogutan, D. K.; Reece, S. Y.; Surendranath, Y.; Teets, T. S.; Nocera, D. G. Chem. Rev. 2010, 110 (11), 6474.

(4) Tsui, E. Y.; Kanady, J. S.; Agapie, T. Inorg. Chem. 2013, 52 (24), 13833.

(5) Sala, X.; Maji, S.; Bofill, R.; García-Antón, J.; Escriche, L.; Llobet, A. Acc. Chem. Res. 2014, 47 (2), 504.

(6) Kok, B.; Forbush, B.; McGloin, M. Photochem. Photobiol. 1970, 11 (6), 457.

(7) Krewald, V.; Retegan, M.; Cox, N.; Messinger, J.; Lubitz, W.; DeBeer, S.; Neese, F.; Pantazis, D. A. Chem. Sci. 2015, 6 (3), 1676.

(8) O’Malley, P. J.; Collins, S. J. Chem. Phys. Lett. 1996, 259 (3-4), 296.

(9) Sinnecker, S.; Neese, F.; Noodleman, L.; Lubitz, W. J. Am. Chem. Soc. 2004, 126 (8), 2613.

(10) Blankenship, R.; Hartman, H. Trends Biochem. Sci. 1998, 23 (3), 94.

(11) Xiong, J.; Bauer, C. E. Annu. Rev. Plant Biol. 2002, 53 (1), 503.

(12) Coates, C. S.; Milikisiyants, S.; Chatterjee, R.; Whittaker, M. M.; Whittaker, J. W.; Lakshmi, K. V. J. Phys. Chem. B 2015, 119 (15), 4905.

(13) McConnell, I. L.; Grigoryants, V. M.; Scholes, C. P.; Myers, W. K.; Chen, P.-Y.; Whittaker, J. W.; Brudvig, G. W. J. Am. Chem. Soc. 2012, 134 (3), 1504.

(14) Siegbahn, P. E. M. Theor. Chem. Acc. 2001, 105 (3), 197.

(15) Siegbahn, P. E. M. J. Comput. Chem. 2001, 22 (14), 1634.

(16) Waldo, G. S.; Yu, S.; Penner-Hahn, J. E. J. Am. Chem. Soc. 1992, 114 (14), 5869.

(17) Schäfer, K.-O.; Bittl, R.; Lendzian, F. J. Phys. Chem. B 2003, 107

(5), 1242.
(18) Stich, T. A.; Whittaker, J. W.; Britt, R. D. J. Phys. Chem. B 2010, 114 (45), 14178.

(19) Gamelin, D. R.; Kirk, M. L.; Stemmler, T. L.; Pal, S.; Armstrong, W. H.; Penner-Hahn, J. E.; Solomon, E. I. J. Am. Chem. Soc. 1994, 116 (6), 2392.

(20) Milikisiyants, S.; Chatterjee, R.; Lakshmi, K. V. J. Phys. Chem. B 2011, 115 (42), 12220.

(21) Usov, O. M.; Grigoryants, V. M.; Tagore, R; Brudvig, G. W.; Scholes, C. P. J. Am. Chem. Soc. 2007, 129 (39), 11886.

(22) Sinnecker, S.; Neese, F.; Lubitz, W. JBIC, J. Biol. Inorg. Chem. 2005, 10 (3), 231.

(23) Schinzel, S.; Kaupp, M. Can. J. Chem. 2009, 87 (10), 1521.

(24) Barynin, V. V.; Whittaker, M. M.; Antonyuk, S. V.; Lamzin, V. S.; Harrison, P. M.; Artymiuk, P. J.; Whittaker, J. W. Structure 2001, 9 (8), 725 .

(25) Orio, M.; Pantazis, D. A.; Petrenko, T.; Neese, F. Inorg. Chem. 2009, 48 (15), 7251.

(26) Rapatskiy, L.; Ames, W. M.; Pérez-Navarro, M.; Savitsky, A.; Griese, J. J.; Weyhermüller, T.; Shafaat, H. S.; Högbom, M.; Neese, F.; Pantazis, D. A.; Cox, N. J. Phys. Chem. B 2015, 119 (43), 13904.

(27) Antonyuk, S. V.; Melik-Adamyan, V. R.; Popov, A. N.; Lamzin, V. S.; Hempstead, P. D.; Harrison, P. M.; Artymyuk, P. J.; Barynin, V. V. Crystallogr. Rep. 2000, 45 (1), 105.

(28) Spiegel, K.; De Grado, W. F.; Klein, M. L. Proteins: Struct., Funct., Genet. 2006, 65 (2), 317. 